\author{
ОБІЗНАНІСТЬ СТУДЕНТІВ У СВОЄРІДНОСТІ ДІЯЛЬНОСТІ \\ УЧИТЕЛІВ-ЛОГОПЕДІВ В УМОВАХ ІНКЛЮЗІЇ ЯК ПЕРЕДУМОВА \\ ÏХНЬОÏ ПРОФЕСІЙНОÏ КОМПЕТЕНТНОСТІ
}

\title{
AWARENESS OF STUDENTS IN THE PECULIARITIES OF THE ACTIVITIES OF SPEECH THERAPIST TEACHERS IN THE CONDITIONS OF INCLUSION AS A PREREQUISITE FOR THEIR PROFESSIONAL COMPETENCE
}

у статті висвітлюються напрями діяльності вчителя-логопеда в умовах інклюзивного навчального простору. Здійснено теоретичне осмислення діяльності вчителя-логопеда та окреслено коло його функціональних обов'язків в умовах інклюзивної школи. Обгрунтовано особливості взаємодї педагога-логопеда $з$ дитиною-логопатом в інклюзивному класі. Подано визначення профресійної діяльності логопеда в умовах інклюзивного навчання як сферу, в якій виявляється професійна активність логопеда, спрямована на вирішення задач з цілеспрямованого впливу на учня в умовах інклюзивного навчання. Доведено, що засвоєні принципи інклюзії актуалізують їх інноваційний вплив на професійну діяльність учителя-логопеда; значно зростає його роль у соціалізаціі дітей-логопатів. З огляду на це визначено та охарактеризовано функції логопеда в інклюзивному класі, серед яких - діагностична, конструктивно-проєктувальна, організачійна, навчально-виховна, корекційна, психологічна, здоров'язбережувальна, комунікативна, рефлексивна. Зазначено, що підготовка майбутніх учителів-логопедів до здійснення відповідних профресійних фрункцій починається ще у вищому навчальному закладі, де прочес навчання спрямований на формування фрахівия, який володіє всіма компетентностями, необхідними для здійснення професійної діяльності. Визначено низку суперечностей, що виникають під час професійної підготовки висококваліфрікованих фрахівиів-логопедів у сучасній вищій педагогічній школі. у статmі подано результати дослідження обізнаності студентів у своєрідності діяльності вчителів-логопедів в умовах інклюзивного навчання. Акцентовано увагу на тому, що особливі умови професійної діяльності вчителя-логопеда висувають нові вимоги до самого педагогічного процесу та його результату. У дослідженні окреслено шляхи підготовки практико-орієнтованих логопедів, готових до інноваційної діяльності. Ключові слова: формування готовності до професійної діяльності майбутніх учителівлогопедів, логопед, функції логопедів в умовах інклюзивного навчання, інклюзія, корекційна роботавінклюзивномунавчальномупросторі.
The article focuses on the activities of a speech therapist teacher in an inclusive learning environment. Theoretical understanding of the activities of a speech therapist teacher has been made and the circle of his functional duties in the conditions of an inclusive school has been outlined. The peculiarities of the interaction of the speech therapist teacher with the child with speech disorders in an inclusive class are substantiated. The professional activities of the speech therapist in the conditions of inclusive training are defined as the sphere in which the professional activity of the speech therapist, aimed at solving the tasks of purposeful influence on the student in the conditions of inclusive learning, is rendered. It is proved that the principles of inclusion, that has been learned, actualize their innovative influence on the professional activity of the speech therapist teacher; his role in the socialization of children with speech disorders is growing significantly. Considering this, the functions of a speech therapist in an inclusive class are defined and characterized, among them: diagnostic, constructive-designing, organizational, training and educational, corrective, psychological, health-saving, communicative, reflexive. It is noted that the preparation of future speech therapists for the implementation of relevant professional functions begins in a higher education institution, where the training process is aimed at forming the specialist who has all the competencies necessary for his professional activity. There are many contradictions that arise in the professional training of highly qualified speech therapists in the modern higher pedagogical school. The article presents the results of the study of students awareness of the peculiarities of the activities of speech therapists in inclusive learning. Special attention is drawn to the fact that special conditions for the professional activity of the speech therapist make new demands on the pedagogical process and its result. The study outlines the ways of preparation of practice-oriented speech therapists ready for the innovative activity. Key words: formation of readiness for professional activity of future speech therapists, speech therapist, functions of speech therapists in terms of inclusive education, inclusion, correctional work in an inclusive educational space. педагогічного університету імені К.Д. Ушинського

Постановка проблеми у загальному вигляді. Нині в Україні, як і в усьому світі, число дітей з особливими освітніми потребами неухильно зростає. За даними Всесвітньої організації охорони здоров'я, чисельність осіб з обмеженими можливостями все більшає. Близько 95 млн (5,1\%) дітей мають інвалідність, 13\% (0,7\%) - тяжку фрорму інвалідності [3, с. 8]. Поряд із цим гуманізація суспільства вимагає усунення бар'єрів, пов'язаних 3 інвалідністю, зокрема й у сорері освіти. Це покликана зробити інклюзивна модель освіти, яка широко впроваджується в нашій країні. Так, 
завдяки інклюзивній рефрормі 12 тисяч дітей з особливими освітніми потребами отримали змогу навчатися в загальноосвітніх школах. Розпочали роботу 487 Інклюзивно-ресурсних центрів [8]. У школах запроваджені посади вчителя-логопеда, психолога, соціального педагога.

Впровадження інклюзивної освіти висуває нові вимоги до підготовки вчителів, у тому числі й до вчителів-логопедів. Принципи інклюзії мають бути інтегровані в програми підготовки вчителів і поєднуватися 3 іншими ініціативами, що дають можливість учителям обмінюватися досвідом і професійними знаннями в галузі інклюзивної освіти. Гнучкості та готовності до прийняття відповідальних рішень, активної співпраці вимагає інклюзивна модель навчання в загальноосвітніх закладах від учителя-логопеда.

Аналіз останніх досліджень і публікацій. Проблема фрормування готовності фрахівців у сорері корекційної освіти, у тому числі логопедів, вивчалася вітчизняними (Ю. Пінчук, Л. Черніченко та ін.) та зарубіжними дослідниками (А. Анісімова, Н. Лавська, Т. Корнійченко, Л. Ястребова та ін.).

Питання підвищення якості підготовки майбутніх учителів-дефектологів до реалізації різних функцій профресійної діяльності у загальноосвітніх навчальних закладів у своїх працях торкались В. Бондар, С. Миронова, Н. Пахомова, К. Островська, В. Тищенко, Д. Шульженко, А. Шевцов, М. Шеремет та ін.

Виділення не вирішених раніше частин загальної проблеми. Водночас, як засвідчує аналіз наукового фронду, підготовка вчителів-логопедів потребує ясного розуміння сутності їхньої профресійної діяльності в нових умовах інклюзивного навчання, виокремлення та розширення фрункцій фрахівця-логопеда та у зв'язку з цим удосконалення практико-орієнтованої підготовки майбутніх учителів-логопедів.

Мета статті полягає в теоретичному осмисленні діяльності вчителя-логопеда та визначенні кола його фрункціональних обов'язків в умовах інклюзивної школи, а також дослідження обізнаності студентів у своєрідності діяльності учителівлогопедів в умовах інклюзивного навчання.

Виклад основного матеріалу. Зростаючі вимоги до якості професійної підготовки висококваліфрікованих фрахівців-логопедів у сучасній вищій педагогічній школі стикаються із низкою суперечностей: між новою якістю життя і вже наявною системою освіти; між теорією та практикою впровадження ідей інклюзивної освіти; між збільшенням кількості дітей, які мають порушення мовлення, що ускладнені вторинними відхиленнями, і недостатньою готовністю логопедів до корекції комбінованих ускладнень; між зростаючими вимогами до професійної майстерності логопедів і недостатнім рівнем їхньої професійної підготовки у вищих навчальних закладах; між зростанням об'єктивної соціальної значущості професії логопеда і фрактичною недооцінкою його праці з боку суспільства. Окрім цього, виникає і низка інших суперечностей між: рівнем розвитку логопедії як науки і рівнем відбиття нового знання в змісті логопедичної освіти; практикою підготовки логопеда, що склалася, і цілями сучасної логопедичної освіти; особистою вмотивованістю студента здобувати логопедичну освіту та нормативною заданістю навчального процесу; гострою потребою розробки ефективної технологічної моделі підготовки логопедів у вищих навчальних закладах і недостатньою розробленістю відповідної моделі в параметрах сучасної логопедичної освіти.

Висуваючи вимоги до професійної компетентності майбутніх фахівців, також варто враховувати особливості інклюзивного освітнього середовища. Серед таких, наприклад, В. Хитрюк на перший план висуває «диверсисрікаційність, яка проявляється: в організаційних умовах (неповторності складу дитячого колективу, що визначається присутністю «особливих» дітей), в змісті освіти («кожній дитині - індивідуальна освітня програма і свій освітній маршрут»), в освітніх результатах (варіативності повноти і глибини формулювання компетенцій у різних дітей), у полісуб'єктності освітнього простору (учасниками інклюзивної освіти стають педагоги, звичайні й «особливі» діти, їхні батьки, вчителі-десектологи, співробітники соціально-психологічних служб закладів освіти тощо), в меті освіти (на перший план виходить соціалізуюча фрункція, фрункція фрормування суб'єктності та соціально значущих компетенцій особистості). Все це детермінує як зміст професійної діяльності педагогів, так і зміст їхньої професійної підготовки та готовності до роботи в інклюзивну освітньому просторі» [7, с. 190].

За визначенням Л. Федорович: «логопед корекційний педагог, що займається усуненням порушень мови й мовлення у дітей, підлітків і дорослих» [6, с. 287].

Профресійна діяльність логопеда в умовах інклюзивного навчання розуміється нами як сорера, в якій виявляється профресійна активність логопеда, спрямована на вирішення задач з цілеспрямованого впливу на учня в умовах інклюзивного навчання.

До особливостей роботи логопеда 3 дитиноюлогопатом можна віднести такі:

1) дитина-логопат перебуває в середовищі з ознаками інклюзії;

2) в інклюзивному освітньому середовищі дитина-логопат має мотивацію, аби стати таким, як інші «звичайні» діти;

3) вчитель-логопед взаємодіє не лише з дитиною 3 особливими освітніми потребами та її батьками, але й з іншими дітьми та їхніми батьками, 
3 педагогічними працівниками, бібліотечним персоналом, педагогами спеціальної освіти та ін.

В інклюзивному середовищі діяльність логопеда не обмежується корекційним впливом. Усе більшого значення набуває сприяння соціалізації дітей з мовленнєвими порушеннями. Як показують спостереження, саме мовленнєві порушення стають перепоною на шляху до безбар'єрного спілкування дітей-логопатів 3 іншими дітьми, нерідко об'єктом насмішок однолітків. Відхилення в мовленнєвій сфері супроводжується у дітей і змінами в емоційно-вольовій сорері, що може стати причиною розвитку негативних якостей характеру (надмірна сором'язливість, замкненість, негативізм). Різні порушення мовлення (як-от заїкання, ринолалія, дизартрія, а також дисграфія та дислексія) ускладнюють засвоєння дітьми шкільної програми, можуть сорормувати негативне ставлення до навчання.

Крім того, діти з вадами мовлення часто мають комбіновані порушення розвитку, зокрема, порушення опорно-рухового апарату (наприклад, ДЦП) та порушення мовлення. Нерідкими є і множинні дефекти, наприклад, за вираженого недорозвинення мовлення наявні невеликі порушення моторики, зору, слуху. Сумарно це дає негативний ефект для загального розвитку дитини.

Вивчення, корекція і навчання таких дітей потребує від учителя-логопеда застосування знань з медицини, психологічних і спеціальних педагогічних наук, глибокого поліпредметного підходу. Разом із тим учитель-логопед в інклюзивному освітньому середовищі має спрямувати свої сили на соціалізацію школярів, побудову здорового мікроклімату в класі задля забезпечення комфортних умов навчання дітей з особливими потребами.

Інклюзивне навчання забезпечує сприятливі умови для досягнення рівних можливостей і повної участі дітей з особливими потребами; для їхньої ефективної діяльності необхідні спільні зусилля не лише педагогів, персоналу навчального закладу, а й учнів-однолітків, батьків [1, с. 30].

У зв'язку з цим фрункції вчителя-логопеда значно розширюються. Окрім розробки індивідуальних освітніх програм, відстеження динаміки розвитку учня, оцінювання його успішності в освоєнні програм, учитель-логопед мусить більше уваги приділяти комунікації з батьками дітей з особливими потребами, батьками інших дітей, вчителями. Це виражається у допомозі педагогам у виборі адекватних методів і засобів навчання, консультуванні батьків, роботі зі «звичайними» дітьми. Адже успішність корекційно-розвивального впливу безпосередньо пов'язана зі здібностями логопеда вибудовувати позитивні стосунки 3 батьками, дітьми та колегами у формі активної взаємодії.

Напрями діяльності вчителя-логопеда в інклюзивному класі такі:
- проведення диференціальної діагностики для визначення типу порушень;

- консультування дітей з відхиленнями в мовленнєвому розвитку, їхніх батьків і педагогів з проблем навчання, розвитку;

- здійснення психопрофрілактичної роботи, яка спрямована на вибудову сприятливого мікроклімату в навчальному закладі;

- здійснення консультаційної роботи педагогів 3 приводу навчання дітей з порушеннями мовлення шкільних дисциплін у загальноосвітніх закладах;

- виховання дітей з мовленнєвою патологією;

- впровадження та культивування здоров'язбережувальних технологій, у тому числі й профрілактики негативних звичок, які шкодять мовленнєвому розвитку дітей.

Н. Лавська виділяє такі функції педагогадеоректолога: діагностичну (вміння бачити різноманітні порушення психічного і фрізичного розвитку дитини, проводити діагностику, розробляти індивідуальний маршрут корекційно-педагогічної роботи), прогностичну (спостереження, прогнозування психічного розвитку дитини), дидактичну (вміння планувати навчальний процес, використовувати сучасні технології в процесі здійснення професійної діяльності, враховуючи індивідуальні особливості психофрізичного розвитку дитини), трансорормаційну (підпорядкування всіх компонентів навчального процесу колекційному принципові), виховну (виховання та соціалізація дитини), організаційну (вміння раціонально вибудовувати навчально-виховний процес, контролювати результати), консультативну (вміння взаємодіяти з батьками, педагогами, вузькопрофрільними спеціалістами), а також соціальну (вивчення умов і можливостей соціальної інтеграції дитини) та комунікативну (взаємодія з дітьми, батьками, педагогами та ін. спеціалістами, що супроводжують розвиток дитини) [4, с. 229-230].

У дослідженнях Г. Волкової [2] виділено 7 фрункцій логопеда: корекційну, навчальну, виховну, дослідницьку, фрункцію психолого-педагогічної освіти батьків, функцію самоосвіти.

У цій класифрікації також підкреслена роль тісної взаємодії з батьками, наголошено на необхідності логопеда проводити дослідницьку діяльність (аналіз передового досвіду, вивчення нового) та постійну роботу над собою, важливість самовдосконалення і саморозвитку для досягнення педагогічної майстерності.

На нашу думку, доречно виділити такі фрункції вчителя-логопеда в умовах інклюзії, як:

- діагностична (вміння проводити діагностику рівня психічного та фрізичного розвитку дитини, виявлення за допомогою адекватно підібраного діагностичного інструментарію причин та умов, що вплинули на мовленнєвий розвиток; встановлення ступеня порушення); 
- конструктивно-проєктувальна (розробка корекційної програми, планування власної дослідно-педагогічної і корекційно-педагогічної діяльності, визначення умов їх практичної реалізації, планування цілей і задач корекційного впливу);

- організаційна (створення сприятливих умов для загального і мовленнєвого розвитку дитини, усунення несприятливих фракторів, що негативно впливають на розвиток дитини, встановлення педагогічно доцільних відносин 3 дітьми 3 порушенням мови, їхніми батьками, надання оперативної педагогічної допомоги дітям 3 порушеннями мови, створення психологічно комсрортної атмосфрери під час організації різних видів діяльності);

- навчально-виховна (сприяння формуванню загальної культури особистості, соціалізації дитини, розвиток пізнавальної мотивації та становлення навчальної самостійності, розширення кругозору тощо);

- корекційна (визначення змісту корекційноосвітніх програм для дітей з порушенням мовлення в умовах різних типів освітніх закладів, застосування методик і технік корекційно-розвиваючої роботи з урахуванням механізмів мовного порушення, структури дефекту, ступеня його виразності задля досягнення позитивного перетворювального еоректу);

- психологічна (здатність застосування знань про вікову психологію дитини);

- здоров'язбережувальна (здатність вирішувати завдання щодо збереження здоров'я власного та здоров'я дітей);

- комунікативна (здійснення ефективної міжособистісної взаємодії, а саме: професійно-педагогічної комунікації, проведення просвітницької діяльності, здатність налагоджувати продуктивну взаємодію з батьками та дітьми в інклюзивному середовищі, суб'єкт-суб'єктну комунікацію);

- рефлексивна (пов'язана з умінням оцінювати результати роботи, здатністю до критичного мислення, а також самоосвіти).

Підготовка майбутніх учителів-логопедів до здійснення відповідних професійних фрункцій починається ще у вищому навчальному закладі, де процес навчання спрямований на фрормування фрахівця, який володіє всіма компетентностями, необхідними для здійснення професійної діяльності. 3 метою визначення обізнаності студентів у своєрідності діяльності учителів-логопедів в умовах інклюзії нами було проведено опитування студентів I-II курсів спеціальності «Спеціальна освіта (логопедія)» Ізмаїльського державного гуманітарного університету.

Більшість респондентів (70\%) визначають інклюзивне освітнє середовище як навчання здорових дітей 3 дітьми 3 особливими освітніми потребами. Можемо констатувати, що студенти перших курсів сепарують дітей на «здорових» i «дітей з особливими освітніми потребами». Водночас інклюзивне освітнє середовище передбачає створення єдиного освітнього простору 3 можливістю розвитку всіх дітей, враховуючи їхні можливості. На жаль, 30\% студентів не замислювалися над цим питанням.

Свій ступінь обізнаності на рівні 10 балів (за 12-бальною шкалою) визначають 50\% респондентів, на рівні 9 балів - інші 50\%.

$34 \%$ опитуваних визначають ступінь своєї готовності до роботи на рівні 6 балів, 16\% - на рівні 7 балів, 50\% - на рівні 8 балів.

Найкориснішими для майбутньої роботи студенти визначають для себе такі навчальні курси, як «Логопедія», «Основи логопедичної гімнастики», «Психолінгвістика».

На середньому рівні (6 балів) студенти II курсу оцінюють володіння уміннями та навичками, необхідними для роботи 3 дітьми з особливими освітніми потребами.

Ставлення майбутніх учителів-логопедів до дітей з особливими освітніми потребами уважне й милосердне (100\% респондентів), що є показником високої емпатії (компонента психологічної готовності до професійної діяльності).

$67 \%$ опитуваних вважають, що спільне навчання і виховання з дітьми з особливими освітніми потребами є корисним для всіх дітей, інші (33\%) - не замислювалися над цим питанням.

Усі респонденти вважають корисним і позитивним поєднання фрункцій логопеда і фрахівця, який створює інклюзивне освітнє середовище.

100\% опитуваних мають інтерес до майбутньої професії, мотивовані до здійснення успішної профресійної діяльності, прагнуть допомагати дітям із дефектами звуковимови. Студенти вже 3 перших курсів розуміють необхідність вдосконалення у професії протягом усього життя та творчого підходу до розв'язання профресійних завдань. А отже, мотиваційний компонент готовності майбутніх учителів-логопедів є сорормованим вже на II курсі.

Серед фрункцій учителя-логопеда 50\% респондентів виділяють корекційну як основну, 34\% респондентів додають ще комунікативну та психологічну фрункції, які визначають як допомогу дітям освоїтися в навколишньому світі. 16\% опитаних взагалі не замислювалися про функції вчителялогопеда. Це означає, що діяльнісний компонент готовності майбутніх учителів-логопедів до роботи не сорормований.

Тож, аби забезпечити фрормування готовності студентів до здійснення професійних обов'язків у нових умовах, мають бути створені відповідні умови, а саме:

- забезпечення фрормування позитивної мотивації студентів до успішної професійної діяльності;

- засвоєння студентами цінностей інклюзивної освіти шляхом удосконалення змісту дисциплін 
правового, культурологічного, соціально-гуманітарного напряму;

- спрямованість кадрів вищого навчального закладу на індивідуалізацію процесу фрормування готовності майбутніх фрахівців до професійної діяльності, фрормування стратегій індивідуального навчання;

- адаптація з метою створення загальної спрямованості навчальних планів та курсів на підготовку кадрів, здатних працювати в нових умовах інклюзивного освітнього простору;

- розробка відповідного методичного забезпечення;

- використання широкого спектра технологічного та методологічного інструментарію;

- забезпечення проходження студентами реальної (а не номінальної) виробничої практики;

- здійснення моніторингу (регулярної проміжної діагностики) процесу фрормування готовності майбутніх учителів-логопедів до роботи в умовах інклюзивного освітнього простору.

Висновки. Отже, можемо констатувати, що діяльність учителя-логопеда $€$ необхідним складником психолого-педагогічного супроводу дітейлогопатів в інклюзивному просторі загальноосвітнього навчального закладу. Вона спрямована на соціалізацію та збереження здоров'я всіх учнів. 3 огляду на це, вважаємо перспективним дослідження проблеми підготовки майбутніх учителівлогопедів до інноваційної діяльності в умовах інклюзії, вироблення теоретичних засад і апробу- вання моделі формування готовності майбутніх учителів-логопедів до роботи в умовах інклюзії.

\section{БІБЛІОГРАФІЧНИЙ СПИСОК:}

1. Басалюк Н.М. Методична робота вчителялогопеда в аспекті інклюзивної освіти. Актуальні питання корекційної освіти. 2010. № 1. С. 29-35.

2. Волкова Г.А., Шаховская С.Н. Логопедия : учебник для студентов дефектологических фракультетов педагогических вузов. Москва : Гуманит. изд. центр ВЛАДОС, 2009. 703 с.

3. Всемирный доклад об инвалидности : резюме. ВО3 : Всемирный банк, 2011. 28 с

4. Лавская Н. Особенности профресссиональной деятельности педагога-дефектолога. Педагогика. Психология. Социальная работа. Ювенология. Социокинетика. 2012. № 31. С. 229-231.

5. Про освіту : Закон України від 05.09.2017 p. № 2145-VIII. Голос України. 2017. 27 верес. (№ 178-179). С. 10-22.

6. Федорович Л. Концептуальні засади підготовки логопеда до роботи з дітьми раннього віку у вищих навчальних закладах в умовах інтеграції в європейський освітній простір. Науковий часопис НПУ імені М.П. Драгоманова. Серія 19: Корекційна педагогіка та спеціальна психологія. 2012. Вип. 21. С. 286-290.

7. Хитрюк В. Готовность педагогов к работе в условиях инклюзивного образования. Вестник ЧГПУ им. И.Я. Яковлева. 2013. № 3 (79). С. 189-194.

8. 12 тисяч дітей 3 особливими потребами сіли за «звичайні парти» - Марина Порошенко. URL: https://www.ukrinform.ua/rubric-society/2575977-12tisac-ditej-z-osoblivimi-potrebami-sili-za-zvicajni-partimarina-porosenko.html (дата звернення: 17.07.2019). 